\title{
Influence of 5-hydroxytryptamine on crypt cell production rate of human duodenal mucosa cultured in vitro
}

\author{
E E WHEELER, D N CHALLACOMBE \\ From the Somerset Children's Research Unit, Musgrove Park Hospital, Taunton, Somerset
}

SUMMARY The effect of 5-hydroxytryptamine (5-HT) on the crypt cell production rate in normal human duodenal mucosa cultured in vitro was studied using a stathmokinetic technique with crypt microdissection. The addition of $5-\mathrm{HT}(2 \mathrm{mg} / \mathrm{ml})$ to the culture medium significantly increased the crypt cell production rate $(p<0.001)$, suggesting that this amine may have a trophic effect on crypt cells in vitro. Increased synthesis and release of 5-HT from enterochromaffin cells in patients with coeliac disease may increase the crypt cell production rate and lead to a flattened small intestinal mucosa.

Studies on the kinetics of crypt cells in the flattened upper small intestinal mucosa of patients with untreated coeliac disease have shown a halving of the crypt cell cycle time and an increase in the absolute number of proliferating cells. ${ }^{12}$ Similar studies on the jejunal mucosa of laboratory rats in vivo have shown a reduction in the crypt cell cycle time and an increased proliferation of crypt cells after intraperitoneal injection of small doses of 5-hydroxytryptamine $(5-\mathrm{HT}){ }^{3}$ Increased concentrations of 5-HT have been found in the duodenal mucosa ${ }^{4}$ and blood ${ }^{5-7}$ both of adults and children with untreated coeliac disease, together with increased urinary excretion of its major metabolite 5-hydroxyindoleacetic acid. ${ }^{8-13}$ 5-hydroxytryptamine has therefore been implicated in the pathogenesis of this disorder. ${ }^{14}$ We have estimated the crypt cell production rate in biopsy specimens of human duodenal mucosa cultured in a basic medium in vitro using a stathmokinetic technique with crypt microdissection. ${ }^{15}$ Results were compared with the crypt cell production rate in similar specimens cultured in the same basic medium with the addition of 5-HT to determine whether this amine influenced crypt cell kinetics in vitro.

\section{Material and methods}

SMALL INTESTINAL BIOPSY SPECIMENS

Biopsy samples of the mucosa in the third or fourth part of the duodenum were obtained via the mouth from 19 adults who were being routinely investigated

Accepted for publication 25 September 1987 for upper gastrointestinal disorders using a fibreoptic endoscope (Olympus GIF 1T). The tissue specimens were placed in cold Leibowitz L-15 medium and then flattened, serosal surface downwards, using aseptic techniques. Each sample was divided into pieces measuring roughly $3 \mathrm{~mm}^{2}$. Samples for routine histopathology were fixed in either $10 \%$ buffered formalin or acetified formol sublimate. Sections $(4 \mu \mathrm{m})$ were cut from each paraffin block and stained with haematoxylin and eosin.

\section{ORGAN CULTURE}

Specimens of duodenal mucosa from each patient were placed serosal surface downwards on a stainless steel grid platform, positioned at one end of a well in a Lux rectangular culture dish (Flow Laboratories). Two different culture media were used. The first was a basic medium comprising: $6 \mathrm{ml}$ of Trowell's T-8 medium, $2 \mathrm{ml}$ of NCTC (National Collection of Type Cultures) 135 medium, $1.5 \mathrm{ml}$ of 309 fetal calf serum (GIBCO), $0.2 \mathrm{ml}$ of L-glutamine ( $200 \mathrm{mM}), 0.05 \mathrm{ml}$ of penicillin and streptomycin ( $5000 \mathrm{U}$ of each), $0.025 \mathrm{ml}$ of amphotericin, and $0.1 \mathrm{ml}$ of HEPES (1 M). The second culture medium consisted of the same basic medium to which 5-hydroxytryptamine creatinine sulphate (Sigma) was added to give a final concentration of $2 \mathrm{mg} / \mathrm{ml}$. After this addition the medium was sterilised by millipore filtration.

Specimens of duodenal tissue from 10 patients (five men and five women) were cultured in basic medium alone, and specimens from nine patients (four men and five women) were cultured in the basic medium with added 5-HT. In each experiment the medium was warmed to $37^{\circ} \mathrm{C}$ and then $2.5 \mathrm{ml}$ was placed in the culture dish. The dish was covered with a lid (slightly 
raised to allow for gassing) and placed in a controlled atmosphere chamber (Bellco Glass Inc) containing a dish of sterile water to maintain humidity. The chamber was sealed, placed on a rocking apparatus in a $37^{\circ} \mathrm{C}$ incubator, and rocked at $4 \mathrm{rpm}$ in an atmosphere of $95 \%$ oxygen and $5 \%$ carbon dioxide to enable only the underside of the tissue to be alternately exposed to the gas phase and to the medium.

\section{CRYPT CELL PRODUCTION RATE}

Specimens of duodenal tissue were maintained in organ culture for 18 hours before adding a further $1 \mathrm{ml}$ of the appropriate culture medium to raise the fluid level and ensure good penetration by the metaphase arresting agent. The stathmokinetic experiment was then started by adding vincristine sulphate (Oncovin, Lilly) to each culture well at a concentration of $1 \mu \mathrm{g} / \mathrm{ml}$. This concentration was derived from earlier studies and was the lowest dose of vincristine sulphate within the range of $0 \cdot 1-3.0 \mu \mathrm{g} / \mathrm{ml}$ that caused the greatest number of metaphase arrests per crypt over three hours without allowing escape into anaphase to occur. After the addition of vincristine sulphate two explants were removed from the culture at hourly intervals for three hours and were fixed in Carnoy's fluid for four hours. The specimens were then stored in $70 \%$ alcohol before staining DNA by the Feulgen technique. Intestinal crypts in each sample were separated by microdissection in $45 \%$ acetic acid and squashed under a coverslip. The number of arrested metaphases in each crypt was then counted. As this number varied considerably throughout the tissue, even in adjacent crypts, at least 15 complete crypts from different parts of the tissue were examined. Counts made at the edges of the tissue did not differ appreciably from those in the centre, and preliminary studies after the addition of ${ }^{3} \mathrm{H}$-thymidine to the culture medium had shown uniform labelling of crypt cell nuclei on autoradiography with no evidence of "edge labelling". The mean number of metaphase arrests per crypt at each sampling time was then plotted for tissue samples cultured in each medium. The slope of the lines joining these points represented the crypt cell production rate (cells/crypt/hour) and was determined by linear regression analysis (least squares). Statistical analysis of the differences between the slopes was performed using Student's $t$ test.

\section{Results}

Histological sections of duodenal mucosa from all the patients studied initially appeared normal when examined by light microscopy (fig 1). After culture for 21 hours the appearances were characterised by shortening of some villi, good preservation of the superficial epithelial cells, and a mantle of cellular debris and mucin on the mucosal surface (fig 2). Any evidence of cell necrosis in the tissue was mainly limited to one or two crypts towards the periphery of the specimen and these were not counted. The overall success of the culture system may have been due to the use of a rocking platform, and to ensuring that the underside of the tissue was alternately exposed to the gas phase and to the medium.

The table and fig 3 show the results of the stathmokinetic studies on specimens cultured in the two media. The crypt cell production rate in the specimens from 10 patients cultured in the basic medium alone was estimated to be 1.2 cells/crypt/hour; in contrast, the rate in specimens from nine patients cultured in the basic medium with added 5-HT was significantly increased to 2.7 cells/crypt/hour ( $p<$ $0.001)$. A close correlation was found between the number of metaphase arrests and time in tissues cultured in the basic medium $(r=0.99)$ and in those cultured in the basic medium with added 5-HT ( $\mathrm{r}=$ 0.98 ).

\section{Discussion}

The results of this study suggest that 5-HT has a trophic effect on crypt cells in normal human duodenal mucosa when cultured in vitro. Further dose related studies are necessary, however, as similar experiments on laboratory rats in vivo showed that small doses of 5-hydroxytryptamine creatinine phosphate (10-100 $\mu \mathrm{g} / \mathrm{kg}$ body weight) increased crypt cell proliferation and shortened the cell cycle time in the jejunal mucosa, while larger doses of this amine $(300 \mathrm{mg} / \mathrm{kg}$ body weight) inhibited crypt cell proliferation. ${ }^{3}$ Previous estimates of the crypt cell production rate in the

Table Arrested metaphases per crypt

\begin{tabular}{|c|c|c|c|c|}
\hline \multirow{2}{*}{$\begin{array}{l}\text { Time after addition of } \\
\text { vincristine (minutes) }\end{array}$} & \multicolumn{2}{|c|}{$\begin{array}{l}\text { Tissue cultured in basic medium } \\
(n=10)\end{array}$} & \multicolumn{2}{|c|}{$\begin{array}{l}\text { Tissue cultured in basic medium }+5-H T \\
(n=9)\end{array}$} \\
\hline & Mean & $S E M$ & Mean & $S E M$ \\
\hline $\begin{array}{r}60 \\
120 \\
180\end{array}$ & $\begin{array}{l}1 \cdot 3 \\
2 \cdot 6 \\
3 \cdot 6\end{array}$ & $\begin{array}{l}0.26 \\
0.29 \\
0.34\end{array}$ & $\begin{array}{l}1 \cdot 9 \\
3 \cdot 7 \\
7 \cdot 3\end{array}$ & $\begin{array}{l}0.52 \\
0.50 \\
1 \cdot 10\end{array}$ \\
\hline
\end{tabular}




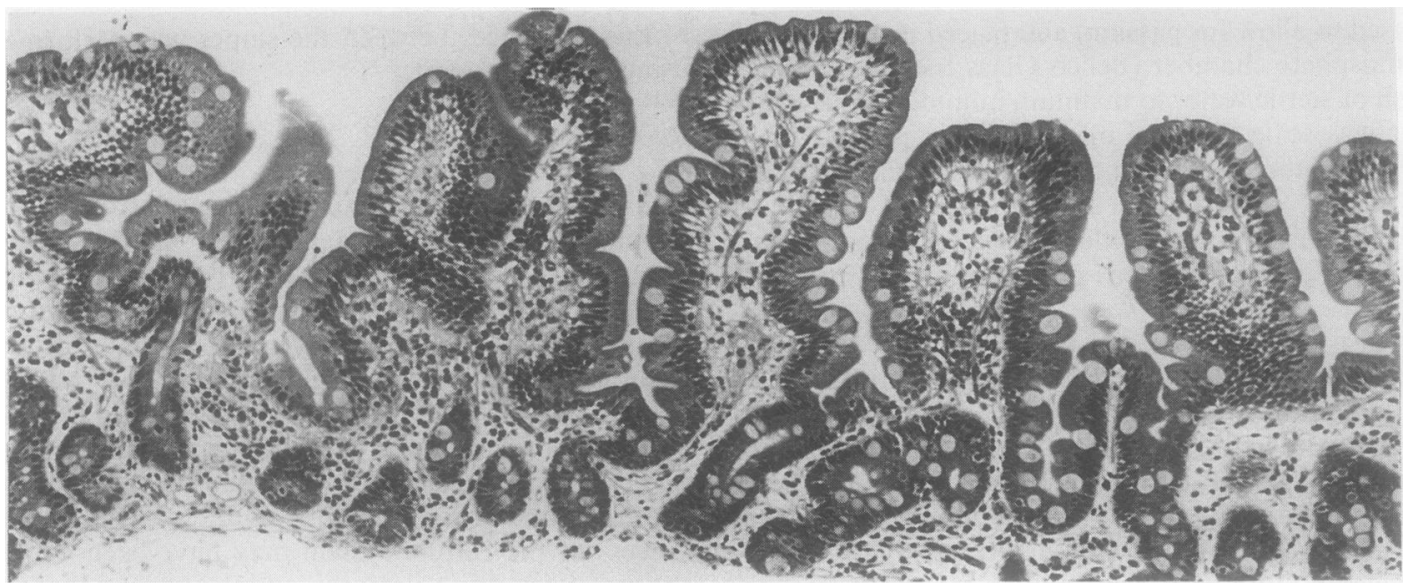

Fig 1 Human duodenal mucosa before culture. (Haematoxylin and eosin.)

normal duodenal mucosa have been derived from morphometric data obtained from histological sections or from histological sections prepared after stathmokinetic studies performed in vivo on two patients. ${ }^{16}$ The crypt cell production rate derived from the histological sections was 17 cells/crypt/hour and was 11 and 14 cells/crypt/hour, respectively, from the sections after the stathmokinetic studies. These values are considerably higher than those obtained in the present study using stathmokinesis and crypt microdissection. It may be possible to increase the crypt cell production rate in vitro by improving the techniques used for culturing the small intestinal mucosa.

In the gastrointestinal tract 5-HT is normally synthesised from dietary tryptophan by enterochromaffin cells, which are present mainly in the crypts of the upper small intestine. Raised concentrations of 5-HT have been found in the duodenal mucosa ${ }^{4}$ and blood $^{5-7}$ of patients with untreated coeliac disease, together with increased urinary excretion of its major metabolite 5-hydroxyindoleacetic acid. ${ }^{8-13}$ These values return to normal after treatment with a gluten free diet. These metabolic abnormalities may be caused by increased synthesis and release of 5-HT by greater numbers of enterochromaffin cells in the upper small intestinal mucosa, which may be secondary to the hyperplasia of all crypt cells in coeliac disease. ${ }^{1718}$ Recent cytofluorometric ${ }^{19}$ and immunohistochemical ${ }^{20}$ studies of enterochromaffin cells also suggest, however, that each cell may synthesise and release greater amounts of 5-HT in coeliac disease. As the crypt cell production rate is increased in the mucosa of the small intestine of patients with coeliac disease $^{2}$ and 5-HT increased the crypt cell production rate in the present study, this amine could be impli-

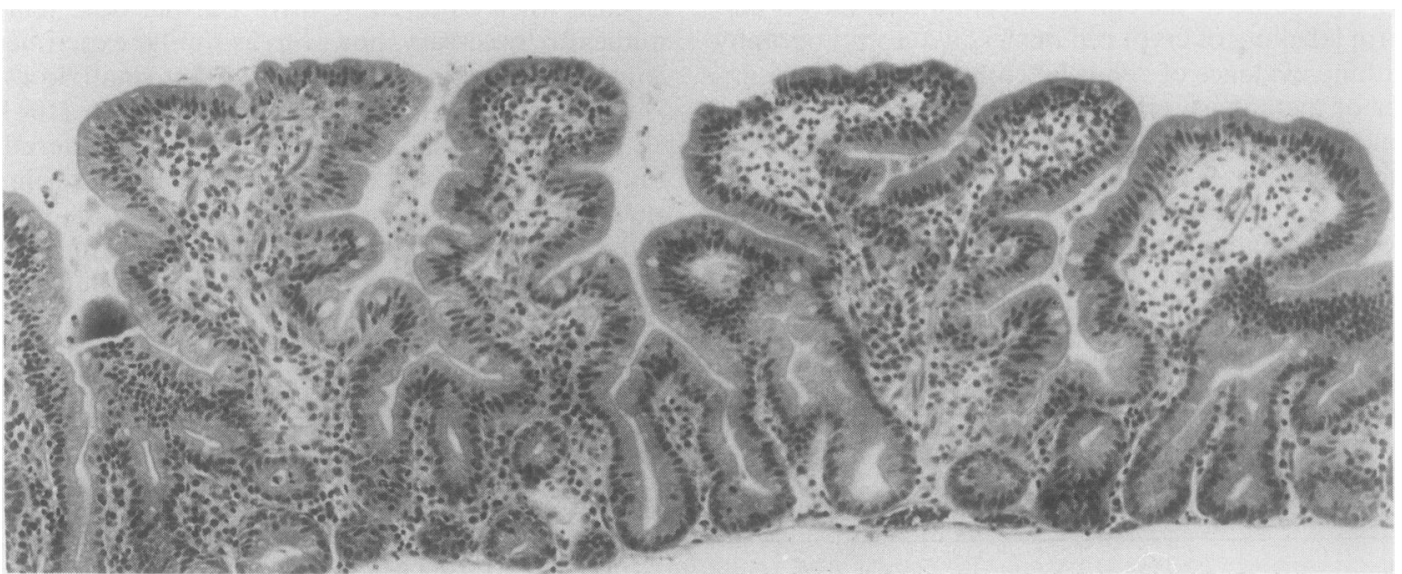

Fig 2 Human duodenal mucosa cultured in basic medium for 24 hours, with cellular debris removed by gentle brushing.

(Haematoxylin and eosin.) 


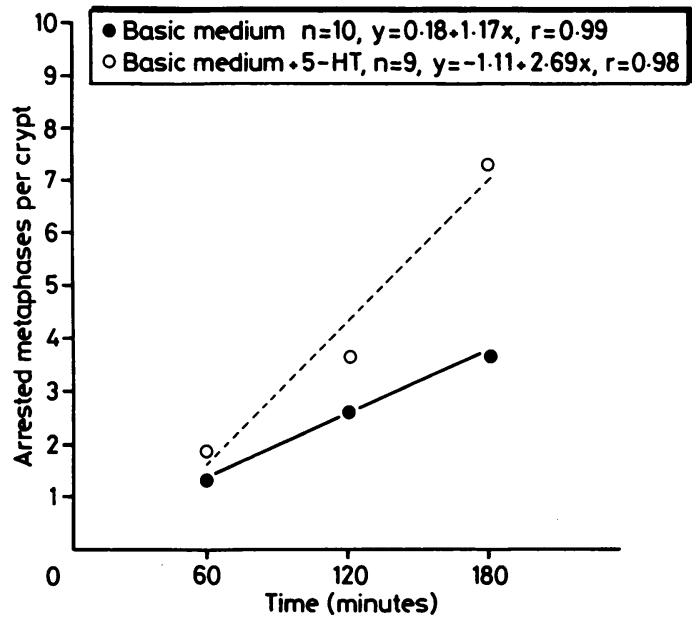

Fig 3 Accumulation of metaphase arrests during stathmokinetic experiments on tissues cultured in both media. Each point represents mean number of arrests in 15 crypts; two tissue samples were analysed at each time point.

cated in the pathogenesis of this disease. It is possible that dietary gluten in patients with coeliac disease stimulates enterochromaffin cells to synthesise and release increased amounts of 5-HT, which increases the crypt cell production rate and leads to a flattened small intestinal mucosa.

Support for this hypothesis might be expected to be found in patients with carcinoid tumours that synthesise increased quantities of 5-HT, but in an earlier study the appearance of the jejunal mucosa on light microscopy in two such patients was normal. ${ }^{21}$ Two recent reports, however, have described patients with carcinoid tumours associated with a flat small intestinal mucosa and coeliac disease, ${ }^{22} 23$ suggesting that further study of the small intestinal mucosa in such patients is indicated.

We thank Dr M Barry, Professor NA Wright, and Mrs Eve Sweet for their advice and support on this project, which was generously supported by members of the Wellington Round Table and Fisons Research and Development Laboratories.

\section{References}

1 Wright N, Watson A, Morley A, Appleton D, Marks J, Douglas A. The cell cycle time in the flat (avillous) mucosa of the human small intestine. Gut 1973;14:603-6.

2 Wright N, Watson A, Morley A, Appleton D, Marks J. Cell kinetics in flat (avillous) mucosa of the human small intestine. Gut 1973;14:701-10.

3 Tutton PJM. The influence of serotonin on crypt cell proliferation in the jejunum of rat. Virchows Arch (Cell Pathol) 1974;16:79-87.
4 Challacombe DN, Dawkins PD, Baker P. Increased tissue concentrations of 5-hydroxytryptamine in the duodenal mucosa of patients with coeliac disease. Gut 1977;18:882-6.

5 Pimparker BD, Senesky D, Kalser MH. Blood serotonin in nontropical sprue. Gastroenterology 1961;40:504-6.

6 Warner RRP, Cohen N. Blood serotonin in malabsorption states. Am J Dig Dis 1962;7:553-6.

7 Sjölund K, Nobin A. Increased levels of plasma 5-hydroxytryptamine in patients with coeliac disease. Scand $J$ Gastroenterol 1985;20:304-8.

8 Kowlessar DW, Williams RC, Law DH, Sleisenger MH. Urinary excretion of 5-hydroxyindoleacetic acid in diarrhoeal states with special reference to nontropical sprue. $N$ Engl $J$ Med 1958:259:340-1.

9 Haverback BJ, Dyce B, Thomas HV. Indole metabolism in the malabsorption syndrome. $N$ Engl J Med 1960;262:754-7.

10 Kowlessar OD, Haeffner LJ, Benson GD. Abnormal tryptophan metabolism in patients with adult coeliac disease with evidence for deficiency of vitamin $B_{6}$. J Clin Invest 1964;43:894-903.

11 Challacombe DN, Brown GA, Black SC, Storrie MH. Increased excretion of 5-hydroxyindoleacetic acid in urine of children with untreated coeliac disease. Arch Dis Child 1972;47:442-8.

12 Challacombe DN, Goodall M, Gaze H, Brown GA. Urinary 5-hydroxyindoleacetic acid in 8-hour collections as an aid in diagnosis of coeliac disease. Arch Dis Child 1975;50:779-81.

13 Challacombe DN, Hammond PGStJ, Crewe P, Dawkins PD. Measurement of the 5-hydroxyindoleacetic acid/creatinine ratio in the urine of patients with coeliac disease. Hepatogastroenterology 1981;28:160-2.

14 Challacombe DN, Dawkins PD, Baker P, Robertson K. 5-hydroxytryptamine metabolism in patients with coeliac disease. In: McNicholl B, McCarthy CF, Fottrell PF, eds. Perspectives in coeliac disease. Lancaster: MTP Press, 1978:413-8.

15 Al-Mukhtar MYT, Polak JM, Bloom SR, Wright NA. The search for appropriate measurements of proliferative and morphological status in studies on intestinal adaptation. In: Robinson JWL, Dowling RH, Riecken E-O, eds. Mechanisms of intestinal adaptation. Lancaster: MTP Press, 1982:3-25.

16 Watson AJ, Wright NA, Appleton DR. Cell proliferation in normal convoluted and avillous small intestinal mucosae of man. In: Appleton DR, Sunter JP, Watson AJ, eds. Cell proliferation in the gastrointestinal tract. Tunbridge Wells: Pitman Medical, 1980:350-63.

17 Challacombe DN, Robertson K. Enterochromaffin cells in the duodenal mucosa of children with coeliac disease. Gut 1977;18:373-6.

18 Sjölund K, Alumets J, Berg N-O, Harkanson R, Sundler F. Enteropathy of coeliac disease in adults: increased number of enterochromaffin cells in the duodenal mucosa. Gut 1982;23:42-8.

19 Enerback L, Hallert C, Norrby K. Raised 5-hydroxytryptamine concentrations in enterochromaffin cells in adult coeliac disease. J Clin Pathol 1983;36:499-503.

20 Wheeler EE, Challacombe DN. Quantification of enterochromaffin cells with serotonin immunoreactivity in the duodenal mucosa in coeliac disease. Arch Dis Child 1984;59:523-7.

21 Melmon KL, Sjoerdsma A, Oates JA, Laster L. Treatment of malabsorption and diarrhoea of the carcinoid syndrome with methysergide. Gastroenterology 1965;48:18-24.

22 Hallert C, Norrby K. Malignant carcinoid tumour complicating coeliac disease. Acta Med Scand 1983;213:313-6.

23 Gardiner GW, Van Patter T, Murray D. Atypical carcinoid tumour of the small bowel complicating coeliac disease. Cancer 1985;56:2716-22.

Requests for reprints to: Dr DN Challacombe, Somerset Children's Research Unit, Taunton and Somerset Hospital, Musgrove Park, Taunton, Somerset TA1 5DA. 